\title{
Influencing Factors of Hearing Disorder in Helicopter and Casa Pilots
}

Faktor-faktor yang Berhubungan dengan Terjadinya Gangguan Pendengaran pada Pilot Helikopter dan Casa

\author{
Nurfitriyana*, July Ivone**, Pramusinto Adhy*** \\ *Faculty of Medicine, Universitas Kristen Maranatha \\ **Department of Public Health, Faculty of Medicine, Universitas Kristen Maranatha \\ ***Department of Ear, Nose, and Throat, Faculty of Medicine, Universitas Kristen Maranatha \\ Jl. Prof. drg. Surya Sumantri MPH No.65 Bandung 40164 Jawa Barat Indonesia \\ Email: fitriiyn@gmail.com
}

Received: August 25, 2019

Accepted: February 18, 2020

\begin{abstract}
Noise-Induced Hearing Loss (NIHL) is a hearing disorder caused by noise. Noise with the intensity of 85 decibels $(d B)$ or higher may damage the corti hearing receptor. Pilot is one of the riskiest occupations due to frequent noise exposure from aircraft machine. This research aimed to identify the influence of aircraft noise levels on hearing disorder of both helicopter and casa pilots. This is observational analytical research with cross-sectional design, involving 30 helicopter pilots and 30 casa pilots. The diagnosis of hearing disorder was done using secondary data from medical records. The aircraft noise was measured by sound level meter, the other risk factors were observed with questionnaire. Data were analyzed by chi-square with $a=0.05$. The results showed that aircraft noise ( $p=0,009 ; O R=4.929)$, duration of working period ( $p=0.026$; $O R=8.308)$, and flight hours ( $p=0.006$; OR=3.222) were related with hearing disorder, but not age $(p=0.093 ;$ OR=3.222). We concluded aircraft noise, duration of the working period, and flight hours are related to hearing disorder of the pilots.
\end{abstract}

Keywords: hearing disorder; pilot; noise; noise-induced hearing loss

\begin{abstract}
Abstrak
Noise Induced Hearing Loss (NIHL) adalah gangguan pendengaran yang disebabkan kebisingan, dapat bersifat sementara atau permanen pada satu atau kedua telinga. Bising dengan intensitas 85 desibel $(\mathrm{dB})$ atau lebih dapat merusak reseptor pendengaran corti di telinga dalam. Pilot merupakan salah satu pekerjaan yang cukup berisiko karena sering terpapar oleh kebisingan yang berasal dari mesin pesawat terbang. Tujuan penelitian adalah mengetahui pengaruh tingkat kebisingan pesawat terhadap fungsi pendengaran pilot helikopter dan pilot casa. Penelitian ini bersifat observasional analitik dengan desain cross sectional. Penelitian dilakukan terhadap 30 orang pilot helikopter dan 30 orang pilot casa. Diagnosis gangguan pendengaran menggunakan data sekunder dari hasil rekam medik. Pengukuran tingkat kebisingan pesawat menggunakan sound level meter, sedangkan faktor risiko lainnya didapatkan dari data kuesioner. Data yang diperoleh akan dianalisis statistik menggunakan uji chi square dengan $\alpha=0,05$. Hasil penelitian didapatkan bahwa kebisingan pesawat berhubungan dengan gangguan pendengaran pada pilot $(\mathrm{p}=0,009 ; \mathrm{OR}=4,929)$, faktor lain yang berhubungan dengan gangguan pendengaran adalah lama
\end{abstract}


masa kerja $(\mathrm{p}=0,026 ; \mathrm{OR}=8,308)$ dan jam terbang $(\mathrm{p}=0,006 ; \mathrm{OR}=6,234)$, sedangkan faktor usia tidak berhubungan dengan gangguan pendengaran pada pilot $(\mathrm{p}=0,093)$. Simpulan dari penelitian ini adalah kebisingan pesawat, lama masa kerja, dan jam terbang berhubungan dengan gangguan pendengaran pada pilot.

Kata kunci: gangguan pendengaran; pilot; kebisingan; noise induced hearing loss

\section{Pendahuluan}

Gangguan pada telinga yang banyak dijumpai di masyarakat salah satunya adalah gangguan fungsi pendengaran, dan hal ini dapat berdampak pada kualitas hidup seseorang. Gangguan pendengaran dapat terjadi karena beberapa faktor yaitu kelainan genetik, komplikasi saat lahir, infeksi telinga kronis, penggunaan obat tertentu, paparan kebisingan yang berlebihan, dan penuaan. ${ }^{1}$

Menurut Peraturan Menteri Kesehatan Nomor 71 8/Menkes/Per/XI/1987, kebisingan adalah terjadinya bunyi yang tidak diinginkan sehingga mengganggu atau dapat membahayakan kesehatan. ${ }^{2}$ Bising dengan intensitas 85 desibel (dB) atau lebih dapat merusak reseptor pendengaran corti di telinga dalam. ${ }^{3}$

Noise-Induced Hearing Loss (NIHL) adalah gangguan pendengaran yang disebabkan kebisingan, bisa bersifat sementara atau permanen pada satu atau kedua telinga. ${ }^{4}$ Kondisi NIHL dapat disebabkan oleh pemaparan satu kali terhadap suara yang intens, seperti ledakan, atau oleh paparan terus menerus terhadap suara keras selama periode waktu yang lama. ${ }^{5}$ Pekerjaan dengan risiko tinggi untuk NIHL termasuk manufaktur, transportasi, pertambangan, konstruksi, pilot, pertanian, dan militer. ${ }^{6,7}$

Pada pertemuan konsultasi WHO-SEARO (South East Asia Regional Office) Intercountry Meeting mengenai pencegahan dan pengendalian ketulian dan gangguan pendengaran, disampaikan bahwa di Indonesia, gangguan pendengaran akibat bising merupakan penyebab gangguan pendengaran ke tiga terbanyak. ${ }^{8}$ Laporan WHO tahun 2018 mengenai ketulian dan gangguan pendengaran menyatakan bahwa 1,1 miliar orang berusia antara 12-35 tahun berisiko kehilangan pendengaran karena paparan kebisingan di tempat rekreasi. ${ }^{1}$

Pilot merupakan salah satu pekerjaan yang cukup berisiko karena sering terpapar oleh kebisingan yang berasal dari mesin pesawat terbang. ${ }^{9}$ Penelitian oleh Pratiwi pada tahun 2012 tentang Pengaruh Tingkat Kebisingan Pesawat Herkules dan Helikopter terhadap Terjadinya Gangguan Pendengaran pada Penerbang TNI AU menunjukkan bahwa penerbang yang terpapar oleh bising helikopter memiliki risiko untuk mengalami gangguan pendengaran akibat bising 2,67 


\section{Research Article}

kali lebih besar daripada penerbang yang terpapar oleh bising herkules. Kebisingan yang dihasilkan oleh pesawat terbang mencapai 95-105 dB(A) bahkan 100-110 dB(A) pada flightdeck bergantung pada jenis pesawat terbang, fase penerbangan, ketinggian, dan cuaca. ${ }^{10}$ Helikopter termasuk ke dalam jenis pesawat rotary wing, sedangkan Casa termasuk ke dalam jenis pesawat fixed wing. Pesawat jenis rotary wing memiliki intensitas bising dan efek getaran yang relatif lebih tinggi dibandingkan pesawat jenis fixed wing. ${ }^{11}$ Tujuan penelitian ini adalah untuk mengetahui pengaruh tingkat kebisingan pesawat pada fungsi pendengaran pilot dari kedua jenis pesawat ini.

\section{Metode}

Metode penelitian yang digunakan pada penelitian ini adalah analitik observasional dengan desain penelitian cross-sectional atau potong lintang yang dilakukan kepada 60 orang pilot. Subjek penelitian ini terdiri atas 30 orang pilot helikopter dan 30 orang pilot casa. Data penelitian didapatkan dengan cara mengukur tingkat kebisingan dengan sound level meter, pengisian kuesioner dan data rekam medis pemeriksaan kesehatan pilot helikopter dan pilot casa dari Skadron-21/Sena Puspenerbad dan Balai Kesehatan Penerbangan Kemayoran Jakarta. Setelah data terkumpul, dianalisis menggunakan uji chi square $(\alpha=0,05)$.

Penelitian ini telah mendapat persetujuan dari Komisi Etik Penelitian Fakultas Kedokteran Universitas Kristen Maranatha dan Rumah Sakit Immanuel dengan nomor surat keputusan 090/KEP/III/2018.

\section{Hasil}

Data subjek penelitian yang dikumpulkan meliputi derajat gangguan pendengaran, usia, masa kerja, dan jam terbang, dan distribusinya tercantum pada tabel 2 dan 3.

Tabel 1 Hasil Pengukuran Tingkat Kebisingan Pesawat Helikopter dan Casa

\begin{tabular}{ccccc}
\hline \multirow{2}{*}{ Jenis pesawat } & \multicolumn{3}{c}{ Tingkat kebisingan } & $\begin{array}{c}\text { Rerata } \\
\text { kebisingan }\end{array}$ \\
\cline { 2 - 4 } & take off & in flight & Landing & $112 \mathrm{~dB}$ \\
Helikopter & $99 \mathrm{~dB}$ & $103 \mathrm{~dB}$ & $104,7 \mathrm{~dB}$ \\
Casa & $95 \mathrm{~dB}$ & $93 \mathrm{~dB}$ & $97 \mathrm{~dB}$ & $95 \mathrm{~dB}$ \\
\hline
\end{tabular}

Tabel 1 menunjukkan bahwa tingkat kebisingan helikopter lebih besar dibandingkan dengan tingkat kebisingan casa. Helikopter terukur lebih bising saat take off, in flight, maupun 
landing. Hasil perhitungan menunjukkan rerata kebisingan pesawat helikopter adalah 104,7 dB sedangkan pesawat casa adalah $95 \mathrm{~dB}$.

Tabel 2 Distribusi Subjek Penelitian Berdasarkan Derajat Gangguan Pendengaran

\begin{tabular}{ccccc}
\hline & \multicolumn{4}{c}{ Jenis pesawat } \\
\cline { 2 - 5 } Status pendengaran & \multicolumn{2}{c}{ Helikopter } & \multicolumn{2}{c}{ Casa } \\
\cline { 2 - 5 } & Jumlah $(\mathrm{n})$ & $\begin{array}{c}\text { Persentase } \\
(\%)\end{array}$ & Jumlah $(\mathrm{n})$ & $\begin{array}{c}\text { Persentase } \\
(\%)\end{array}$ \\
\hline Normal & 14 & 46,67 & 23 & 76,67 \\
Tuli ringan & 14 & 46,67 & 7 & 23,33 \\
Tuli sedang & 2 & 6,67 & 0 & 0 \\
\hline Total & 30 & 100 & 30 & 100 \\
\hline
\end{tabular}

Berdasarkan tabel di atas, diketahui bahwa pada 30 orang pilot helikopter terdapat 14 orang pilot dengan status pendengaran normal, 14 orang pilot dengan status pendengaran tuli ringan, dan 2 orang pilot dengan stasus pendengaran tuli sedang. Pada 30 orang pilot casa didapatkan 23 orang pilot dengan status pendengaran normal, dan 7 orang pilot dengan status pendengaran tuli ringan.

Tabel 3 Distribusi Subjek Penelitian Meliputi Usia, Masa Kerja, dan Jam Terbang

\begin{tabular}{lcc}
\hline \multicolumn{1}{c}{ Karakteristik } & $\begin{array}{c}\text { Jumlah } \\
(\mathrm{n}=60)\end{array}$ & $\begin{array}{c}\text { Persentase } \\
(\%)\end{array}$ \\
\hline Usia & & \\
$<40$ tahun & 44 & $73,3 \%$ \\
$\geq 40$ tahun & 16 & $26.7 \%$ \\
Masa kerja & & \\
$\quad<5$ tahun & 10 & $83,3 \%$ \\
$\geq 5$ tahun & 50 & \\
Jam terbang & & $38,3 \%$ \\
$<1500$ jam & 23 & $61,7 \%$ \\
$\geq 1500$ jam & 37 &
\end{tabular}

Berdasarkan tabel di atas, distribusi subjek penelitian berdasarkan usia menunjukkan bahwa sebanyak 44 orang pilot $(73,3 \%)$ berusia $<40$ tahun dan 16 orang pilot $(26,7 \%)$ pilot berusia $\geq 40$ tahun. Distribusi subjek penelitian berdasarkan masa kerja menunjukkan bahwa sebanyak 10 orang pilot $(16,7 \%)$ memiliki masa kerja $<5$ tahun dan 50 orang pilot $(83,3 \%)$ memiliki masa kerja $\geq 5$ tahun. Distribusi subjek penelitian berdasarkan jam terbang 


\section{Research Article}

menunjukkan bahwa sebanyak 23 orang pilot $(38,3 \%)$ memiliki jam terbang $<1.500$ jam dan 37 orang pilot $(61,7 \%)$ memiliki jam terbang $\geq 1.500$ jam.

Tabel 4 Hubungan Tingkat Kebisingan Terhadap Gangguan Pendengaran

\begin{tabular}{|c|c|c|c|c|c|c|}
\hline \multirow[b]{2}{*}{ Variabel } & \multirow[b]{2}{*}{ Kategori } & \multicolumn{2}{|c|}{ Status pendengaran } & \multirow{2}{*}{$\begin{array}{l}\text { Jumlah } \\
\mathrm{N}(\%)\end{array}$} & \multirow[b]{2}{*}{$p$-value } & \multirow[b]{2}{*}{ OR } \\
\hline & & $\begin{array}{l}\text { Normal } \\
\mathrm{N}(\%)\end{array}$ & $\begin{array}{c}\text { Terganggu } \\
\mathrm{N}(\%)\end{array}$ & & & \\
\hline \multirow{2}{*}{$\begin{array}{l}\text { Tingkat } \\
\text { kebisingan }\end{array}$} & Casa & $23(76,7)$ & $7(23,3)$ & $30(100)$ & $0,009 *$ & 4,929 \\
\hline & Helikopter & $12(40)$ & $18(60)$ & $30(100)$ & & \\
\hline
\end{tabular}

*Terdapat hubungan yang bermakna

Pada tabel 4 didapatkan hasil analisis uji statistik hubungan tingkat kebisingan dengan terjadinya gangguan pendengaran dengan nilai $\mathrm{p}=0,009$ dan nilai $\mathrm{OR}=4,929$ yang berarti terdapat hubungan yang bermakna antara tingkat kebisingan dengan terjadinya gangguan pendengaran pada penerbang helikopter dan casa. Penerbang yang terpapar oleh bising pesawat helikopter mempunyai risiko terjadinya gangguan pendengaran 4,929 kali dibandingkan dengan penerbang yang terpajan oleh bising pesawat casa.

Tabel 5 Hubungan Usia Terhadap Gangguan Pendengaran

\begin{tabular}{|c|c|c|c|c|c|c|}
\hline \multirow{2}{*}{ Variabel } & \multirow{2}{*}{ Kategori } & \multicolumn{2}{|c|}{ Status pendengaran } & \multirow{2}{*}{$\begin{array}{l}\text { Jumlah } \\
\mathrm{N}(\%)\end{array}$} & \multirow{2}{*}{ p-value } & \multirow{2}{*}{ OR } \\
\hline & & $\begin{array}{l}\text { Normal } \\
\mathrm{N}(\%)\end{array}$ & $\begin{array}{c}\text { Gangguan } \\
\mathrm{N}(\%)\end{array}$ & & & \\
\hline \multirow[t]{2}{*}{ Usia } & $<40$ tahun & $29(65,9)$ & $15(34,1)$ & $44(100)$ & 0,093 & 3,222 \\
\hline & $\geq 40$ tahun & $6(37,5)$ & $10(62,5)$ & $16(100)$ & & \\
\hline
\end{tabular}

Pada tabel 5 didapatkan hasil analisis uji statistik hubungan usia dengan terjadinya gangguan pendengaran dengan nilai $p=0,093$. Hal ini menunjukkan bahwa tidak terdapat hubungan yang bermakna antara penerbang berusia $<40$ tahun dan penerbang berusia $\geq 40$ terhadap gangguan pendengaran akibat bising. 
Research Article

Tabel 6 Hubungan Masa Kerja terhadap Gangguan Pendengaran

\begin{tabular}{|c|c|c|c|c|c|c|}
\hline \multirow{2}{*}{ Variabel } & \multirow{2}{*}{ Kategori } & \multicolumn{2}{|c|}{ Status pendengaran } & \multirow{2}{*}{$\begin{array}{c}\text { Jumlah } \\
\mathrm{N}(\%)\end{array}$} & \multirow{2}{*}{$p$-value } & \multirow{2}{*}{ OR } \\
\hline & & $\begin{array}{c}\text { Normal } \\
\mathrm{N}(\%)\end{array}$ & $\begin{array}{c}\text { Gangguan } \\
\mathrm{N}(\%)\end{array}$ & & & \\
\hline \multirow[t]{2}{*}{ Masa kerja } & $<5$ tahun & $9(90)$ & $1(10)$ & $10(100)$ & $0,026^{*}$ & 8,308 \\
\hline & $\geq 5$ tahun & $26(52)$ & $24(48)$ & $50(100)$ & & \\
\hline
\end{tabular}

* Terdapat hubungan yang bermakna

Pada tabel 6 didapatkan hasil analisis uji statistik hubungan masa kerja dengan terjadinya gangguan pendengaran dengan nilai $\mathrm{p}=0,026$ dan nilai $\mathrm{OR}=8,308$ yang berarti terdapat hubungan yang bermakna antara penerbang dengan masa kerja $<5$ tahun dan penerbang dengan masa kerja $\geq 5$ tahun. Penerbang yang memiliki masa kerja $\geq 5$ tahun mempunyai risiko terjadinya gangguan pendengaran 8,308 kali dibandingkan dengan penerbang yang memiliki masa kerja $<5$ tahun.

Tabel 7 Hubungan Jam Terbang terhadap Gangguan Pendengaran

\begin{tabular}{|c|c|c|c|c|c|c|}
\hline \multirow{2}{*}{ Variabel } & \multirow{2}{*}{ Kategori } & \multicolumn{2}{|c|}{ Status pendengaran } & \multirow{2}{*}{$\begin{array}{l}\text { Jumlah } \\
\mathrm{N}(\%)\end{array}$} & \multirow{2}{*}{ p-value } & \multirow{2}{*}{ OR } \\
\hline & & $\begin{array}{l}\text { Normal } \\
\mathrm{N}(\%)\end{array}$ & $\begin{array}{c}\text { Gangguan } \\
\mathrm{N}(\%)\end{array}$ & & & \\
\hline \multirow{2}{*}{$\begin{array}{l}\text { Jam } \\
\text { terbang }\end{array}$} & $<1500$ jam & $19(82,6)$ & $4(17,4)$ & $23(100)$ & $0,006^{*}$ & 6,234 \\
\hline & $>1500$ jam & $16(43,2)$ & $21(56,8)$ & 37 (100) & & \\
\hline
\end{tabular}

Pada tabel 7 didapatkan hasil analisis uji statistik hubungan jam terbang dengan terjadinya gangguan pendengaran dengan nilai $\mathrm{p}=0,006$ dan nilai $\mathrm{OR}=6,234$ yang berarti terdapat hubungan yang bermakna antara penerbang dengan jam terbang $<1.500$ jam dan penerbang dengan jam terbang $\geq 1.500$ jam. Penerbang yang memiliki jam terbang $\geq 1.500$ jam mempunyai risiko terjadinya gangguan pendengaran 6,234 kali dibandingkan dengan penerbang yang memiliki jam terbang $<1.500$ jam.

\section{Diskusi}

Uji chi square menunjukkan adanya perbedaan bermakna antara gangguan pendengaran pada penerbang helikopter dan casa dengan nilai $\mathrm{p}<0,05$. Hasil pengukuran tingkat kebisingan menunjukkan pesawat helikopter mempunyai intensitas bising yang lebih tinggi dibanding pesawat casa karena posisi mesin yang tepat berada di atas kepala penerbang. ${ }^{11}$ Paparan bising 


\section{Research Article}

intensitas tinggi secara berulang dapat menimbulkan kerusakan sel-sel rambut organ korti di telinga bagian dalam. Kerusakan dapat terlokalisasi di beberapa tempat di koklea atau di seluruh sel rambut di koklea. Hal ini dapat menyebabkan disfungsi sel-sel rambut yang mengakibatkan gangguan ambang pendengaran sementara atau bahkan kerusakan sel-sel rambut yang mengakibatkan gangguan ambang pendengaran yang permanen. ${ }^{12}$

Hasil penelitian ini sejalan dengan penelitian yang dilakukan Dewi Pratiwi pada tahun 2012 terhadap penerbang TNI AU yang menunjukkan adanya perbedaan yang bermakna antara penerbang yang terpapar oleh bising helikopter dibandingkan dengan herkules $(p=0,025) .{ }^{11}$ Penelitian sebelumnya juga dilakukan pada tahun 2013 mengenai prevalensi dan faktor risiko tuli akibat bising pada operator kapal feri yang menunjukkan perbedaan yang bermakna antara operator mesin kapal feri yang terpapar bising $\leq 85 \mathrm{~dB}$ dan $>85 \mathrm{~dB}$ dengan nilai $\mathrm{p}=0,006 .{ }^{13}$ Penelitian lainnya dilakukan Joneri pada tahun 2013 terhadap karyawan yang bekerja di apron Bandara Supadio Pontianak menunjukkan, terdapat pengaruh yang bermakna antara intensitas kebisingan dengan gangguan kemampuan pendengaran dengan nilai $\mathrm{p}=0,04 .^{8}$

Uji chi square menunjukkan tidak ada hubungan yang bermakna antara usia dengan terjadinya gangguan pendengaran $(\mathrm{p}>0,05)$. Kondisi NIHL yang terjadi pada usia $\geq 40$ tahun selain berhubungan dengan faktor bising, kemungkinan berhubungan dengan penurunan ambang pendengaran karena faktor usia atau presbikusis. ${ }^{13}$ Gangguan pendengaran terkait usia dapat terjadi karena berkurangnya sel rambut koklea yang bersifat progresif, dimana hal tersebut diperkirakan mulai terjadi sejak usia 40 tahun. ${ }^{11}$ Faktor yang mempengaruhi presbikusis antara lain adalah usia, jenis kelamin, genetik, hipertensi, diabetes melitus, hiperkolesterol, paparan bising, dan merokok. ${ }^{14}$ Hal ini sejalan dengan penelitian yang dilakukan pada tahun 2012 terhadap penerbang TNI AU dengan hasil uji statistik $\mathrm{p}=0,799$, artinya tidak terdapat perbedaan yang bermakna antara penerbang yang berusia $<35$ tahun dengan yang berusia $\geq 35$ tahun terhadap gangguan pendengaran akibat bising. ${ }^{11}$ Penelitian lainnya dilakukan Darmawan pada tahun 2014 mengenai hubungan karakteristik individu dengan nilai ambang dengar pada tenaga kerja di PT Bangun Sarana Baja Gresik yang menunjukkan hasil uji statistik nilai $p=0,492$ yang artinya tidak ada hubungan yang bermakna antara umur tenaga kerja dengan nilai ambang dengar. ${ }^{15}$ Penelitian lain juga dilakukan Kusumawati pada tahun 2012 mengenai hubungan tingkat kebisingan di lingkungan kerja dengan kejadian gangguan pendengaran pada pekerja di PT X yang menunjukkan hasil uji statistik $\mathrm{p}=0,13$ yang artinya tidak ada hubungan yang bermakna antara umur dengan kejadian gangguan pendengaran. ${ }^{16}$ 


\section{Research Article}

Uji chi square menunjukkan adanya hubungan yang bermakna antara masa kerja dengan terjadinya gangguan pendengaran $(\mathrm{p}<0,05)$. Semakin lama waktu seseorang tersebut terpapar oleh kebisingan maka akan semakin besar risiko kerusakan pada fungsi pendengarannya. Penurunan pada fungsi pendengaran terjadi pada tenaga kerja yang terpapar oleh kebisingan selama 5 tahun atau lebih. ${ }^{3}$ Paparan bising jangka panjang akan menyebabkan pergeseran nilai ambang pendengaran yang bersifat sementara Temporary Threshold Shift (TTS) yang pada akhirnya akan bersifat permanen Permanent Threshold Shift (PTS) jika paparan terus belanjut. ${ }^{11}$ Hasil penelitian ini sejalan dengan penelitian yang dilakukan Dewi Pratiwi pada tahun 2012 terhadap penerbang TNI AU yang menunjukkan adanya perbedaan yang bermakna antara penerbang yang memiliki masa kerja $<5$ tahun dengan penerbang yang memiliki masa kerja $\geq 5$ tahun (nilai $\mathrm{p}=0,015$ ). ${ }^{11} \mathrm{Hal}$ ini sejalan dengan penelitian Jumali pada tahun 2013 mengenai prevalensi dan faktor risiko tuli akibat bising pada operator kapal feri yang menunjukkan hasil uji statistik dengan nilai $\mathrm{p}=0,016$ yang berati terdapat perbedaan yang bermakna antara operator mesin kapal feri yang memiliki masa kerja $<10$ tahun dan yang memiliki masa kerja $\geq 10$ tahun. ${ }^{13}$ Penelitian lain dilakukan Salfi pada tahun 2013 mengenai hubungan tingkat kebisingan terhadap fungsi pendengaran karyawan yang bekerja di PLTG Medan yang menunjukkan perbedaan yang bermakna antara lama masa kerja dengan kejadian Gangguan Pendengaran Akibat Bising (GPAB) $(\mathrm{p}=0,0001){ }^{17}$

Uji chi square menunjukkan adanya hubungan yang bermakna antara jam terbang dengan terjadinya gangguan pendengaran $(\mathrm{p}<0,05)$. Jam terbang dapat menggambarkan keterampilan (skill) responden yang memengaruhi kinerja dalam mengendalikan pesawat tersebut selain kemampuan (ability) dan lingkungan (environment). Kebisingan yang diterima responden berlangsung sejak masa pendidikan dan berlanjut sampai ke dunia kerja. Semakin tinggi jam terbang yang diperoleh maka pengalaman, tingkatan dan frekuensi pajanan terhadap bising akan semakin tinggi. Ambang pendengaran yang terus meningkat, frekuensi pajanan yang terus menerus tanpa adanya pemulihan akan meningkatkan risiko terjadinya ketulian permanen. ${ }^{10,18}$ Penelitian yang dilakukan oleh Kandou tahun 2013 mengenai hubungan karakteristik dengan peningkatan ambang pendengaran pada penerbang menunjukkan hasil terdapat hubungan signifikan antara jam terbang dengan peningkatan ambang pendengaran dengan $\mathrm{p}=0,008$ untuk telinga kanan dan $\mathrm{p}=0,033$ untuk telinga kiri. ${ }^{10}$ Hasil penelitian ini sejalan dengan penelitian yang dilakukan Dewi Pratiwi pada tahun 2012 terhadap penerbang TNI AU yang menunjukkan adanya perbedaan yang bermakna antara penerbang yang memiliki jam terbang $<500$ dengan penerbang yang memiliki jam terbang $\geq 500 .{ }^{11}$ Penelitian lainnya dilakukan Kartika pada tahun 2017 
terhadap penerbang Puspenerbad Ahmad Yani Semarang menunjukkan hubungan yang signifikan antara jam terbang dengan ambang dengar kedua telinga personel Puspenerbad Semarang $(\mathrm{p}=0,000) \cdot{ }^{18}$

\section{Simpulan}

Pilot helikopter lebih banyak mengalami gangguan pendengaran dibandingkan pilot casa. Lama masa kerja dan jumlah jam terbang juga berhubungan dengan gangguan pendengaran pada pilot, sedangkan usia tidak berhubungan dengan gangguan pendengaran pada pilot.

\section{Daftar Pustaka}

1. World Health Organization (WHO). Deafness and hearing loss. 2018. [Cited 2018 April 4]. Available from : http://www.who.int/mediacentre/factsheets/fs300/en/

2. KESMAS. Pengertian dan katagori kebisingan. 2013. [Cited 2018 April 4], Available from : http://www.indonesianpublichealth.com/pengertian-dan-katagori-kebisingan/

3. Soepardi EA, Iskandar N, Bashiruddin J, Restuti RD. Buku Ajar Ilmu Kesehatan Telinga Hidung Tenggorok Kepala dan Leher Edisi 7. Badan Penerbit FKUI: Jakarta; 2012. h. 17-20, 42-5.

4. National Institute on Deafness and Other Communication Disorders (NIDCD). Noice-induced hearing loss. 2014. [Cited 2018 April 4], Available from : https://www.nidcd.nih.gov/health/noise-induced-hearing-loss

5. Centers for Disease Control and Prevention (CDC). Noise-induced hearing loss. 2016. [Cited 2018 April 4], Available from : https://www.cdc.gov/ncbddd/hearingloss/noise.html

6. Barrientos MC, Lendrum DC, Steenland K. Occupational noise. Environmental Burden of Disease Series, No. 9. 2004. [Cited 2018 April 4], Available from : http://www.who.int/quantifying_ehimpacts/publications/en/ebd9.pdf

7. Siagian M, Basuki B, Kusmana D. High intensity interior aircraft noise increases the risk of high diastolic blood pressure in Indonesian Air Force pilots. Med J Indones. 2009; 4(18):276-82.

8. Joneri A. Pengaruh faktor-faktor paparan bising mesin pesawat terbang terhadap gangguan kemampuan pendengaran pada karyawan yang bekerja di Apron Bandara Supadio Pontianak pada Bulan Januari 2011. Program Studi Pendidikan Dokter Fakultas Kedokteran Universitas Tanjungpura, Pontianak, 2013.

9. Drake R, Vogl AW, Mitchell A. Gray’s Anatomy for Students, 2nd Edition. Elsevier; 2010.

10. Kandou LF, Mulyono. Hubungan karakteristik dengan peningkatan ambang pendengaran penerbang di Balai Kesehatan Penerbang Jakarta. The Indonesian Journal of Occupational Safety and Health. 2013; 1(2):1-9.

11. Pratiwi, D. Pengaruh tingkat kebisingan pesawat herkules dan helikopter terhadap terjadinya gangguan pendengaran pada penerbang TNI AU. Program Pendidikan Dokter Spesialis Ilmu Kesehatan THT-KL Fakultas Kedokteran Universitas Sebelas Maret, Surakarta, 2012.

12. Gunara M. Bahaya kebisingan di lingkungan kerja pada industri penarikan kawat dan metode pengendaliannya. Rekayasa Teknologi. 2011; 2(2):31-40.

13. Jumali, Sumadi, Andriani S, Subhi M, Suprijanto D, Handayani WD, dkk. Prevalensi dan faktor risiko tuli akibat bising pada operator mesin kapal feri. Jur Kes Mas Nas. 2013; 7(12): 545-50.

14. Fatmawati R, Dewi YA. Karakteristik penderita presbiakusis di Bagian Ilmu Kesehatan THT-KL RSUP Dr Hasan Sadikin Bandung periode Januari 2012 - Desember 2014. Jurnal Sistem Kesehatan. 2014; 4(1): 201-5. Mohon diperbaiki penulisan nama jurnal ssuai abbreviation

15. Darmawan V, Mulyono. Hubungan karakteristik individu dengan nilai ambang dengar pada tenaga kerja di PT Bangun Sarana Baja Gresik. J Kes Ling. 2014; 2(7): 134-9.

16. Kusumawati I. Hubungan tingkat kebisingan di lingkungan kerja dengan kejadian gangguan pendengaran pada pekerja di PT X. Fakultas Kesehatan Masyarakat Program Studi Kesehatan Masyarakat Universitas Indonesia, Depok, 2012.

17. Salfi E, Adnan A, Haryuna TSH, Zamzam M. Hubungan tingkat kebisingan terhadap fungsi pendengaran karyawan yang bekerja di pusat listrik tenaga gas (PLTG) Medan. J Med School. 2013; 1(46):29-34

18. Kartika, D. Hubungan usia, jam terbang, dan masa kerja dengan ambang dengar penerbang (Studi di Puspenerbad Semarang tahun 2016). Fakultas Kesehatan Masyarakat Universitas Muhamadiyah Semarang. 2017. 